\title{
Adiabated flowing streams in nozzles: influence of regular characteristics on relaxation steam formation
}

\author{
O. Chekh ${ }^{1 \bowtie}$, S. Sharapov ${ }^{2}$, V. Arsenyev ${ }^{3}$
}

Sumy State University, Rimskogo-Korsakova st., 2, Sumy, 40007, Ukraine

$\triangle$ e-mail: o.cheh@kttf.sumdu.edu.ua

ORCID: ${ }^{1} 0000-0003-2500-481 X,{ }^{2} 0000-0002-8433-8580,{ }^{3} 0000-0002-0247-8767$

\begin{abstract}
Two-phase nozzles, in which the phase transition process takes place, can work in jet superchargers for various purposes, including jet thermal pumps (steam-water injectors) and thermal compressors. In such schemes of thermal transformers, the ejector performs the function of a preliminary compression stage in order to reduce the load on the compression of the working substance in the main compressor. The use of fluxes of boiling liquid as energy-efficient working fluids is inhibited due to the lack of a reliable description of the mechanism of their flow. Finding the dependence of the steam content on the pressure and temperature at the nozzle exit will make it possible to determine the variant of the initial parameters at which the overproduction of steam will be greatest. It is also worth determining the change in the velocity factor, as well as the change in the thrust of the nozzle in the studied range of parameters, in order to find out whether the pressure at the nozzle outlet is a determining factor when choosing the design parameters of the nozzles. The article proposes to investigate the boiling streams in such nozzles by the method of mathematical modeling using a model that takes into account the relaxation nature of vaporization. The study used a compressible two-phase medium model, a kinetic model of evaporation / condensation. The model also takes into account the dynamic and mechanical equilibrium of the process of evaporation-condensation. The calculations were performed using an Ansys CFX commercial CFD product. The value of the mean square relative error of pressure measurement does not exceed 0,119\%. The average discrepancy between the obtained data between the mathematical model and the field experiment does not exceed $3 \%$.
\end{abstract}

Keywords: Energy efficiency; Thermocompressor jet unit; Liquid-vapor compressor; Laval nozzle; CFD-modeling.

doi:

(C) The Author(s) 2019. This article is an open access publication

This work is licensed under the Creative Commons Attribution 4.0 International License (CC BY) http://creativecommons.org/licenses/by/4.0/

\section{Introduction}

The generally accepted point of view on the flow mechanism has not yet been formed; it is accompanied by the formation of critical regimes and structural transitions in two-phase flows of boiling accelerating fluid. The lack of a reliable quantitative description of this process inhibits the use of boiling streams as energy efficient working fluids, primarily in jet blowers for various purposes, including jet thermal pumps (steam-water injectors) and thermocompressors. In such schemes of thermotransformers, the ejector performs the function of a preliminary degree of compression in order to reduce the load on the compression of the working substance in the main compressor.

The use of fluxes of boiling liquid as energy-efficient working fluids is inhibited due to the lack of a reliable description of the mechanism of their flow. Finding the dependence of steam content on the initial pressure and temperature will make it possible to determine the variant of the initial parameters at which steam overproduction will be greatest. The boiling streams in such nozzles can be investigated using mathematical modeling.

The results of numerical simulation can clearly reveal the three-dimensionality of the flow in the nozzles, as well as the location and shape of the vapor distribution, which can help to better understand the flow in the nozzles and ultimately put forward ways to optimize them.

Therefore, the purpose of this work is to study the effect of pressure and temperature at the inlet to the nozzle on the steam content.

\section{Literature review}

Ejectors are widely used in various industries. Air and water vapor often serve as working substances.

Hemidi et al. [1] it is shown that an increase in the mass steam content leads to a decrease in the entrainment ratio.

In the nozzles of two-phase ejectors, a process of relaxation vaporization occurs, accompanied by a phase transition of the liquid to vapor. Such a process can be 
modeled using a model based on the Rayleigh-Plesset bubble equation.

Qin et al. [2] found that jet turbulence can create cavitation bubbles when the pressure is close to $2 \mathrm{MPa}$ or less. A comparison with an experiment conducted in a cavitation chamber shows good agreement for different nozzles operating at different pressures.

Results Guoyi et al. [3] and Ma et al. [4] show that the phase transition occurs in the throat of the expanding nozzle when the pressure drops sharply, and the mass transfer rate reaches a maximum. When the pressure at the nozzle outlet reaches $1.65 \mathrm{MPa}$, the volumetric steam content reaches 0.93. A comparison of the calculated and experimental results shows that the maximum relative error of pressure is less than $10.1 \%$, and the temperature is less than $1.9 \%$.

Two-phase ejectors operating on $\mathrm{H}_{2} \mathrm{O}$ and $\mathrm{CO}_{2}$ as part of heat pumps were investigated by the authors [5-7].

In work Bulinski et al. [5] it was established that with a decrease in pressure in ejector with $9 \mathrm{MPa}$ at the input, up to $4 \mathrm{MPa}$ at the output massive vapor content increases from 0 to 0.005 .

In Smolka et al. [6] found that at the exit from the carbon ejector a two-phase mixture, on average, reaches a volumetric steam content of 0.6.

By Colarossi et al. [7] CFD modeling was performed using the OpenFOAM library. Near the centerline, the mass steam content is very close to zero, and along the top wall the mass steam content is close to 0.02 . The equilibrium mass fraction at the exit is zero. The mass steam content at the outlet is less for a higher outlet pressure $(0.23$ at 1.5 $\mathrm{MPa}$ and 0.1 at $2.7 \mathrm{MPa}$ ). No information for different input pressures.

The article by Zhang et al. [8] shows the dependence of the volumetric steam content on pressure at pressures of $0.5,2,8,32 \mathrm{MPa}$. The highest steam content is observed at pressures of 0.5-2 MPa. There are no intermediate points in this area, which makes it impossible to analyze this range of parameters completely.

In Bai et al. [9] shows the distribution of steam volume at an initial pressure of $15.5 \mathrm{MPa}$, and at an outlet pressure of $0.4-2.4 \mathrm{MPa}$. The highest steam content is observed at $0.4 \mathrm{MPa}$ at the outlet. It is shown that with an increase in the length of the diffuser, the steam content at the outlet of the device also increases.

Aung et al. found that cavitation increases with increasing inlet pressure of the nozzle [10]. Cavitation phenomena in nozzles are modeled under flow conditions with different inlet pressures, from $1 \mathrm{MPa}$ to $7 \mathrm{MPa}$. Unfortunately, in this work, there are no generalized data of mass steam content.

Based on the literature review, it can be concluded that the study of the effect of inlet pressure on the output steam content has not been fully studied. There is no information on the amount of steam content in the nozzles at pressures up to 20 times the back pressure. In this paper, CFD modeling is used to study relaxation vaporization in an expanding nozzle.

\section{Research methodology}

An important aspect when choosing the geometry of a nozzle is the question of the efficiency of the conversion of the potential mechanical and thermal energy of hot water into the kinetic energy of the flow. The efficiency of the nozzle can be evaluated using the coefficient of speed:

$$
\varphi_{a}=w_{a} / w_{a s},
$$

where $w_{a}$ - the flow velocity at the outlet of the nozzle, $w_{a s}$ - the the theoretical (equilibrium) flow velocity.

$$
w_{a s}=\sqrt{2\left(h_{0}-h_{a}^{\prime}-\left(s_{0}-s_{a}^{\prime}\right) \cdot T_{a}\right)},
$$

where $h_{0}$ - enthalpy of water at the entrance to the nozzle (from the table of water); $h_{a}{ }^{\prime}$ - enthalpy of water at the outlet of the nozzle (from the saturation table); $s_{0}$ - entropy of water at the entrance to the nozzle (from the table of water); $s_{a}{ }^{\prime}$ - entropy of water at the outlet of the nozzle (from the saturation table); $T_{a}$ - the temperature at the outlet of the nozzle (from the saturation table).

Experimentally, expanded nozzles with a diffusion angle of $14^{\circ}$. The pressure at the inlet to the nozzle $P_{01}=$ $3.1 \mathrm{MPa}$, the temperature $t_{01}=100^{\circ} \mathrm{C}$, the pressure at the outlet of the nozzle $P_{2}=6.8-92.3 \mathrm{kPa}$ (see Table 1).

The object of the study in this paper is the axially symmetric nozzle of Laval, whose geometric dimensions are represented on (Fig. 1). The inlet of the tapered part of the nozzle is a cone with an angle at the apex of $60^{\circ}$. The neck of the nozzle is cylindrical, diameter $5 \mathrm{~mm}$, length 8 $\mathrm{mm}$. The expanding part of the nozzle is formed by two conical surfaces. The throat of the nozzle passes into a cone with an angle at the vertex of $28^{\circ} 40^{\prime}$, which then goes into a cone with an angle at the vertex of $20^{\circ}$. Total degree of nozzle expansion 179.6. The figure shows a sample for studying the distribution of pressures along the length of the flow section of the nozzle. There are 11 drainage openings for pressure tests. The first hole is located at the outlet of the cylindrical throat of the nozzle, the last hole at a distance of $2 \mathrm{~mm}$ from the outlet section of the nozzle. Drainage holes with copper pipes of $3 \mathrm{~mm}$ in diameter are connected to the connections on the wall of the vacuum cavity.

\begin{tabular}{|c|c|c|c|}
\hline $\begin{array}{c}\text { Mode } \\
\text { number }\end{array}$ & $\mathrm{P}_{\text {inlet, }} \mathrm{KPa}$ & $\mathrm{T}_{\text {inlet }},{ }^{0} \mathrm{C}$ & $\mathrm{P}_{\text {outlet, }} \mathrm{KPa}$ \\
\hline 1 & \multirow{5}{*}{3100} & \multirow{5}{*}{100} & 6,8 \\
\hline 2 & & & 30,7 \\
\hline 3 & & & 52,7 \\
\hline 4 & & & 73,7 \\
\hline 5 & & & 92,3 \\
\hline
\end{tabular}

Table 1 - Boundary conditions

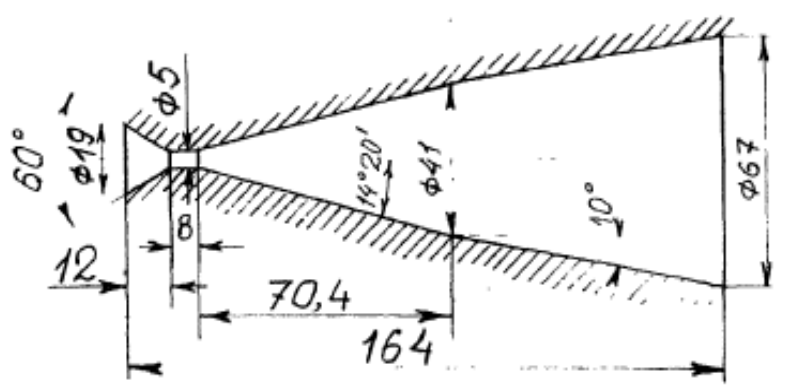

Figure 1 - Flat-parallel nozzle 
In order to model the hydrodynamic processes in the nozzle, a package of computational fluid dynamics ANSYS CFX [11] was used in this paper.

Modeling of flow in nozzles was carried out on the basis of Navier-Stokes equations. Compression was taken in mind. In order to account for turbulence, a k- $\varepsilon$ model was used which represents a joint solution of the Navier-Stokes equations for time-varying components of the variables and additional equations for determining the pulsating components [11]:

- equation of continuity (conservation of mass);

- equation of motion (momentum conservation);

- equation for the transport of kinetic energy of turbulence;

- equation of dissipation of the kinetic energy of turbulence.

In order to account for the phenomenon of cavitation, the available ANSYS CFX model based on the RayleighPleset equation [11] was used, which calculates the dynamics of the growth of the vapor bubble. In this case, the mass transfer between the liquid and the steam is calculated according to the equations of vaporization and condensation.

A three-dimensional nozzle generated a tetrahedron mesh with a condensation near the wall with more than 150,000 elements. At the same time, periodic boundary conditions were superimposed on the model.

\section{Results}

In fig. 2 shows the distribution of pressure along the expanding Laval nozzle with the outflow of water with parameters $\mathrm{P}_{0}=3.1 \mathrm{MPa}$ and $\mathrm{T}_{0}=100^{\circ} \mathrm{C}$. The data were obtained as a result of a physical and numerical experiment and compared them to each other. The value of the mean square relative measurement error pressure does not exceed $0.119 \%$. The average discrepancy between the experimental data and the mathematical model does not exceed $3 \%$.

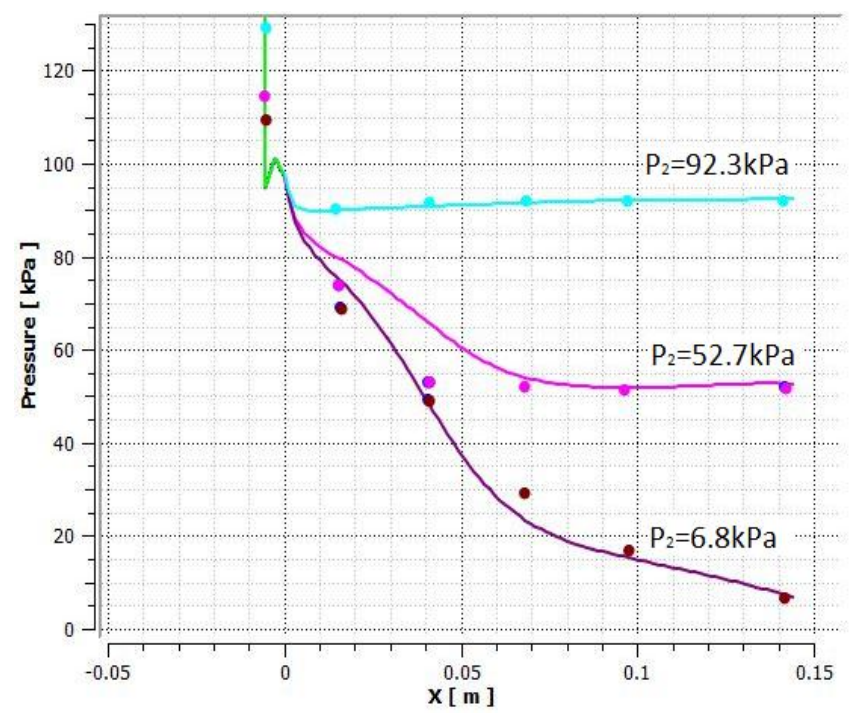

Figure 2 - Static pressure distribution along the length of the expanding part of the axisymmetric Laval nozzle at the confluence of water with parameters $P_{0}=3.1 \mathrm{MPa}$ and $T_{0}=100^{\circ} \mathrm{C}$ :

- - experimental results, $--C F D$ modelling
In the tapering part of this nozzle, water is accelerated, its pressure decreases, in the immediate vicinity of the throat, the local pressure reaches the saturation pressure, the process of relaxation vaporization is initiated, and a mixture of steam and water already leaves the nozzle.

As can be seen from fig. 4, the main differential pressure is triggered in the narrowing part of the Laval nozzle. The liquid phase gradually goes to steam. The highest vapor concentration is observed near the nozzle wall, while the metastable liquid moves in the center. Further downstream, the liquid jet is destroyed, however, the mass fraction of vapor increases.

Studies of the operation of nozzles on water with a large underheating of the saturation line were carried out at an installation for measuring reactive force (thrust developed by a nozzle), described in [12].

Consider the operation of the nozzle for different conditions of water outflow strongly underheated to the saturation temperature at the entrance. In fig. 3 shows the dependence of the change in experimentally measured thrust of the nozzle $\mathrm{R}_{\mathrm{e} \text { (nozzle) }}$ on the temperature of the working water at the inlet and the pressure behind the nozzle $\mathrm{P}_{2}$ at $\mathrm{P}_{0}=3.1 \mathrm{MPa}$.

When the nozzle operates in the design mode of pressure and density of the steam-water mixture in the outlet section of the nozzle, they are the same, both in the working jet and in the environment. However, this mode of operation of the nozzle is performed only under strictly defined conditions $-\mathrm{P}_{\mathrm{a}}=\mathrm{P}_{2}$, and only in this case the thrust of the nozzle:

$$
R_{e(\text { nozzle })}=\left(G_{a}+G_{n}\right) \cdot c_{2},
$$

where $c_{2}=c_{a}$ is the actual flow rate of the steam-water mixture from the nozzle.

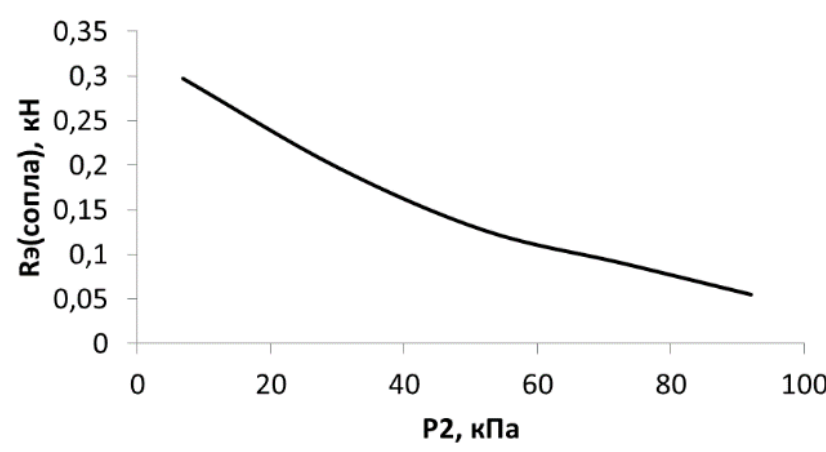

Figure 3 -Dependence of change in the thrust of the nozzle $\operatorname{Re}$ (nozzle) on the pressure behind the nozzle $P_{2}$ at $P_{0}=3.1$ $\mathrm{MPa}$

In fig. 4 shows the dependence of the mass steam content at the nozzle outlet on the back pressure at constant values of the inlet pressure and temperature.

From the graph it is seen that in the studied range of parameters, an increase in mass steam content with increasing back pressure is observed.

In fig. 5 shows the dependence of the change in the velocity coefficient $\varphi$ on the backpressure $\mathrm{P}_{2}$ at a constant pressure of working water in front of the nozzle $\mathrm{P}_{0}=3.1$ $\mathrm{MPa}$ and temperature $\mathrm{T}_{0}=100^{\circ} \mathrm{C}$. 


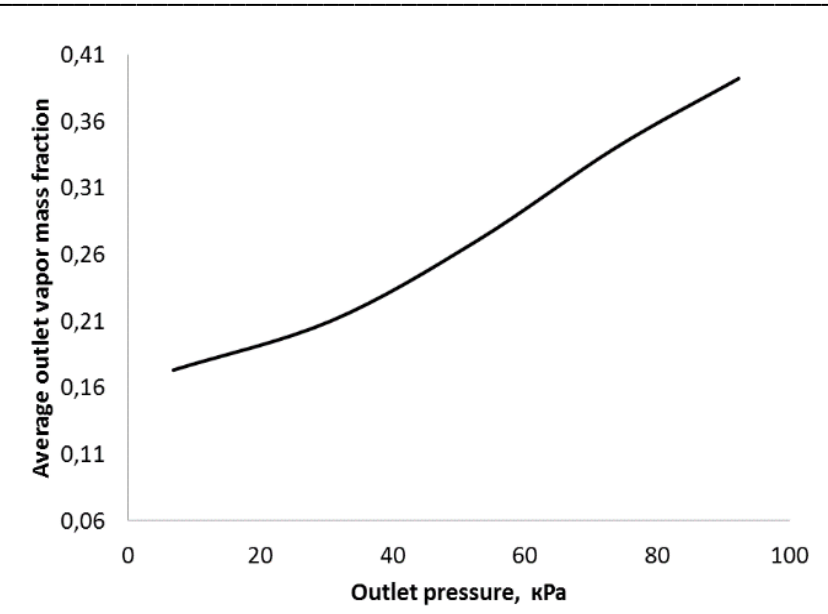

Figure 4 - The value of mass steam content depending on the backpressure

It can be seen from the graph that the velocity coefficient in the investigated range of back pressure varies considerably in magnitude. This value is in the range of values $\varphi=0.4-0.8$ and has a maximum at $\mathrm{P} 2=40-60$ $\mathrm{kPa}$. This suggests that back pressure is a determining factor in the pressure range studied, since significant changes in back pressure lead to significant changes in the velocity ratio.

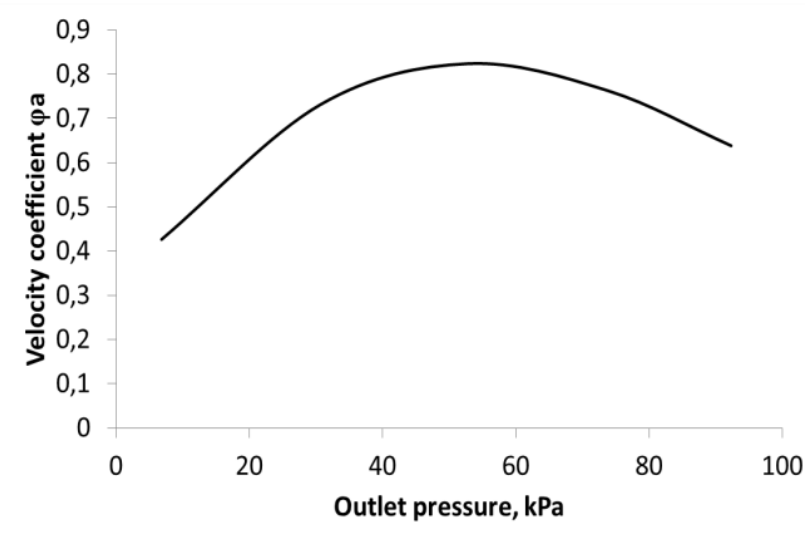

Figure 5-Nozzle velocity ratio versus backpressure

\section{Conclusions}

With an increase in backpressure, the steam content at the nozzle exit also increases. This relationship is linear, and a further increase in pressure leads to an increase in mass steam content.

Backpressure is a determining factor in the pressure range studied, since significant changes in backpressure lead to significant changes in the velocity coefficient.

It was established that the coefficient of speed in the studied range of parameters varies significantly in magnitude. This value is in the range of values $\varphi=0.4-0.8$ and has a maximum at $\mathrm{P}_{2}=40-60 \mathrm{kPa}$.

\section{References}

1. Hemidi, A., Henry, F., Leclaire, S., Seynhaeve, J. M., Bartosiewicz, Y. (2009). CFD analysis of a supersonic air ejector. Part I: Experimental validation of single-phase and two-phase operation. Applied Thermal Engineering, 29(8), 1523-1531.

https://doi.org/10.1016/j.applthermaleng.2008.07.003

2. Qin, Z., Bremhorst, K., Alehossein, H., Meyer, T. (2007). Simulation of cavitation bubbles in a convergentdivergent nozzle water jet. Journal of Fluid Mechanics, 573, 1-25. https://doi.org/10.1017/s002211200600351x

3. Guoyi, P., Congxin, Y., Oguma, Y., Shimizu, S. (2016). Numerical analysis of cavitation cloud shedding in a submerged water jet. Journal of Hydrodynamics, Ser. B, 28(6), 986-993. https://doi.org/10.1016/s10016058(16)60700-x

4. Ma, J., Sun, W., Liu, C., Hou, Y. (2013). Numerical simulation of decompression expansion of subcritical $\mathrm{CO} 2$ through converging-diverging nozzle. Dongbei Daxue Xuebao. Journal of Northeastern University, 34(8), 11751178 .

5. Bulinski, Z., Smolka, J., Fic, A., Banasiak, K., \& Nowak, A. (2010). A comparison of heterogenous and homogenous models of two-phase transonic compressible $\mathrm{CO} 2$ flow through a heat pump ejector. In IOP Conference Series: Materials Science and Engineering, 10(1), 012019. https://doi.org/10.1088/1757-899x/10/1/012019

6. Smolka, J., Bulinski, Z., Fic, A., Nowak, A. J., Banasiak, K., Hafner, A. (2013). A computational model of a transcritical R744 ejector based on a homogeneous real fluid approach. Applied Mathematical Modelling, 37(3), 1208-1224. https://doi.org/10.1016/j.apm.2012.03.044

7. Colarossi, M., Trask, N., Schmidt, D.P., Bergander, M.J. (2012). Multidimensional modeling of condensing two-phase ejector flow. International Journal of Refrigeration, 35(2), 290-299.

https://doi.org/10.1016/j.ijrefrig.2011.08.013

8. Zhang, H., Han, B., Yu, X. G., Ju, D. Y. (2013). Numerical and experimental studies of cavitation behavior in water-jet cavitation peening processing. Shock and Vibration, 20(5), 895-905.

https://doi.org/10.1155/2013/910613

9. Bai, W., Duan, Q., Zhang, Z. (2016). Numerical investigation on cavitation within letdown orifice of PWR nuclear power plant. Nuclear Engineering and Design, 305, 230-245. https://doi.org/10.1016/j.nucengdes.2016.05.013

10. Aung, N. Z., Li, S. (2014). A numerical study of cavitation phenomenon in a flapper-nozzle pilot stage of an electrohydraulic servo-valve with an innovative flapper shape. Energy Conversion and Management, 77, 31-39. https://doi.org/10.1016/j.enconman.2013.09.009

11. ANSYS, INC. (2009). CFX-Solver Theory Guide. $390 \mathrm{p}$.

Received 04 January 2019 Approved 05 February 2019 Available in Internet 03 March 2019 


\title{
Адіабатні закипаючі потоки у соплах: вплив режимних характеристик на релаксаційне пароутворення
}

\author{
О. Чех, С. Шарапов, В. Арсеньєв \\ Сумський державний університет, вул. Римського-Корсакова, 2, м. Суми, 40007, Україна
}

\begin{abstract}
Двофазні сопла, в яких відбувається процес фазового переходу, можуть працювати в струминних нагнітачах різного призначення, включаючи струминні термонасоси (пароводяні інжектори) та термокомпресори. У подібних схемах термотрансформаторів, ежектор виконує функиію попереднього ступеня компресії з метою зниження навантаження на стискання робочої речовини в основному компресорі. Використання закипаючих потоків рідини у якості енергоефективних робочих тіл гальмується через відсутність достовірного опису механізму їх течії. Знаходження залежності паровмісту від тиску $i$ температури на виході з сопла дасть можливість визначити варіант початкових параметрів, при якому перевиробництво пари буде найбільшим. Також варто визначити зміну коефіцієнта швидкості, а також зміну тяги сопла в дослідженому діапазоні параметрів, з метою з'ясування, чи є тиск на виході $з$ сопла визначальним фактором при виборі розрахункових параметрів сопел. Встановлено, щчо коефіцієнт швидкості в досліджуваному діапазоні параметрів значно варіює. Це значення знаходиться в діапазоні значень 0.4-0.8 та має максимум тисках 40-60 кПа. У статті пропонується досліджувати закипаючі потоки в таких соплах методом математичного моделювання за допомогою моделі, яка враховує релаксаційний характер пароутворення. У дослідженні використовувалася модель стисливого двофазного середовища, кінетична модель випаровування / конденсації. Модель також враховує динамічну та механічну рівноважність процесу випаровування-конденсаиії. Обчислення виконувалися за допомогою комериійного CFD продукту Ansys CFX. Величина середньої квадратичної відносної похибки вимірювання тиску не перевищує 0,119\%. Середня розбіжність отриманих даних між математичною моделлю і натурних експериментом не перевищує $3 \%$.
\end{abstract}

Keуwords: енергоефективність; струминний термокомпресорний модуль; рідинно-паровий струминний компресор; сопло Лаваля; CFD-моделювання.

\section{Література}

1. Hemidi, A., Henry, F., Leclaire, S., Seynhaeve, J. M., Bartosiewicz, Y. CFD analysis of a supersonic air ejector. Part I: Experimental validation of single-phase and twophase operation. Applied Thermal Engineering, 2009. Vol. 29, Iss. 8. P. 1523-1531.

2. Qin, Z., Bremhorst, K., Alehossein, H., Meyer, T. Simulation of cavitation bubbles in a convergent-divergent nozzle water jet. Journal of Fluid Mechanics, 2007. Vol. 573. P. 1-25.

3. Guoyi, P., Congxin, Y., Oguma, Y., Shimizu, S. (2016). Numerical analysis of cavitation cloud shedding in a submerged water jet. Journal of Hydrodynamics, Ser. B, 2016. Vol. 28, iss. 6. P. 986-993.

4. Ma, J., Sun, W., Liu, C., Hou, Y. Numerical simulation of decompression expansion of subcritical $\mathrm{CO} 2$ through converging-diverging nozzle. Dongbei Daxue Xuebao. Journal of Northeastern University, 2013. Vol. 34, iss. $8,1175-1178$.

5. Bulinski, Z., Smolka, J., Fic, A., Banasiak, K., Nowak, A. A comparison of heterogenous and homogenous models of two-phase transonic compressible $\mathrm{CO} 2$ flow through a heat pump ejector. In IOP Conference Series: Materials Science and Engineering, 2010. Vol. 10, iss. 1. P. 012019.
6. Smolka, J., Bulinski, Z., Fic, A., Nowak, A. J., Banasiak, K., Hafner, A. A computational model of a transcritical R744 ejector based on a homogeneous real fluid approach. Applied Mathematical Modelling, 2013. Vol. 37, iss. 3. P. 1208-1224.

7. Colarossi, M., Trask, N., Schmidt, D.P., Bergander, M.J. Multidimensional modeling of condensing twophase ejector flow. International Journal of Refrigeration, 2012, Vol. 35, iss. 2. P. 290-299.

8. Zhang, H., Han, B., Yu, X. G., Ju, D. Y. Numerical and experimental studies of cavitation behavior in water-jet cavitation peening processing. Shock and Vibration, 2013. Vol. 20, iss. 5. P. 895-905.

9. Bai, W., Duan, Q., Zhang, Z. Numerical investigation on cavitation within letdown orifice of PWR nuclear power plant. Nuclear Engineering and Design, 2016. Vol. 305. P. 230-245

10. Aung, N. Z., Li, S. A numerical study of cavitation phenomenon in a flapper-nozzle pilot stage of an electrohydraulic servo-valve with an innovative flapper shape. Energy Conversion and Management, 2014. Vol. 77. P. 31-39.

11. ANSYS, INC. CFX-Solver Theory Guide. 2009. 390 p. 